\title{
MATERNAL EXPERIENCES WITH SPECIFICITIES OF PREMATURITY THAT HINDER BREASTFEEDING ${ }^{1}$
}

\author{
Luciana Barbosa Pereira², Ana Cristina Freitas de Vilhena Abrão ${ }^{3}$, Conceição Vieira da Silva Ohara4, Circéa \\ Amália Ribeiro ${ }^{5}$
}

\begin{abstract}
${ }^{1}$ Excerpt from the thesis - Ressignificando o aleitamento materno: do ideal ao impossível: o caminhar da mãe do bebê prematuro rumo ao desmame precoce, submitted to the Nursing Graduate Program of the Universidade Federal de São Paulo (UNIFESP), in 2013

${ }^{2}$ M.Sc. Professor, Department of Nursing, Universidade Estadual de Montes Claros. Montes Claros, Minas Gerais, Brazil. Email: lubper@hotmail.com

${ }^{3}$ Ph.D. in Nursing. Associate Professor, Department of Nursing in Women's Health, Escola Paulista de Enfermagem, UNIFESP. São Paulo, São Paulo, Brazil. E-mail: ana.abrao@unifesp.br

${ }^{4}$ Ph.D. in Nursing. Associate Professor, Department of Pediatric Nursing, UNIFESP. São Paulo, São Paulo, Brazil. E-mail: c.ohara@unifesp.br

${ }^{5}$ Ph.D. in Nursing. Associate Professor, Department of Pediatric Nursing, UNIFESP. São Paulo, São Paulo, Brazil. E-mail: caribeiro@unifesp.br
\end{abstract}

\begin{abstract}
A qualitative study which has Symbolic Interactionism as theoretical framework and Interpretative Interactionism as its methodological one, aiming to unveil motherly experiences against prematurity peculiarities that hinder breastfeeding during infant's hospitalization at the Neonatal Intensive Care Unit. Were interviewed 13 mothers of preterm infants assisted at an Outpatient Follow-up Clinic of Montes Claros MG, Brazil. Results show that as trying to breastfeed a premature infant, the mother interacts with situations signified by her as obstacles to breastfeeding: the "torment" of their child's hospitalization and clinical instability, the fear of baby's death, its difficulty to suck, the late start of breastfeeding interpreted a something difficult, as a risk to weight. We consider that although breastfeeding a preterm infant is a challenge, appropriate professional conducts and hospital procedures might facilitate it and therefore should be implemented, aiming at promoting, protecting and supporting breastfeeding.
\end{abstract}

DESCRIPTORS: Premature. Breastfeeding. Weaning. Neonatal nursing.

\section{VIVÊNCIAS MATERNAS FRENTE ÀS PECULIARIDADES DA PREMATURIDADE QUE DIFICULTAM A AMAMENTAÇÃO}

\begin{abstract}
RESUMO: Estudo qualitativo, tendo como referencial teórico o Interacionismo Simbólico, e metodológico, o Interacionismo Interpretativo, objetivando desvelar as vivências maternas frente às peculiaridades da prematuridade que dificultam a amamentação durante a internação do bebê na Unidade de Terapia Intensiva Neonatal. Foram entrevistadas 13 mães de recém-nascidos prematuros atendidas em Ambulatório de Follow-up do município de Montes Claros MG, Brasil. Resultados revelaram que ao tentar amamentar o filho, a mãe interage com situações significadas por ela como obstáculos à prática da amamentação: o "tormento" da hospitalização do filho, sua instabilidade clínica, o medo da morte do bebê, sua dificuldade para sugar, o início tardio da amamentação interpretada como algo difícil, como risco ao seu ganho de peso. Consideramos que, embora a amamentação de prematuros seja um desafio, condutas profissionais e rotinas hospitalares adequadas às suas especificidades podem facilitar essa prática e devem ser desenvolvidas, visando à promoção, proteção e apoio ao aleitamento.
\end{abstract}

DESCRITORES: Prematuro. Aleitamento materno. Desmame. Enfermagem neonatal.

\section{VIVENCIAS MATERNAS, ANTE LAS PECULIARIDADES DE LA PREMATURIDAD, QUE DIFICULTAN EL ACTO DE AMAMENTAR}

RESUMEN: Estudio cualitativo, que utilizó como referencial teórico el Interaccionismo Simbológico y como metodológico el Interaccionismo Interpretativo con el objetivo de revelar las vivencias maternas frente a las peculiaridades de la prematuridad que dificultan el acto de amamantar durante la internación del bebé en Unidad de Terapia Intensiva Neonatal. Fueran entrevistadas 13 madres de recién nacidos prematuros, atendidas en Ambulatorio de Follow-up, municipio de Montes Claros MG, Brasil. Los resultados revelaron que al intentar amamantar al hijo prematuro, la madre interacciona con situaciones significadas por ella como obstáculos al amamantamiento: el "tormento" de la hospitalización del hijo, su inestabilidad clínica, miedo de muerte del bebé, su dificultad en succionar el pecho, el inicio tardío del amamantamiento interpretado como algo difícil y riesgoso al gaño de peso. Consideramos que, aunque el proceso de amamantamiento del recién nacido prematuro sea un verdadero desafío, conductas profesionales y rutinas hospitalarias adecuadas facilitan la práctica y deben ser incentivadas.

DESCRIPTORES: Prematuro. Lactancia materna. Destete. Enfermería neonatal. 


\section{INTRODUCTION}

Early weaning, defined as the introduction of foods other than breast milk for the baby, before sixth months of age remains an uncomfortable reality in our country, despite all the efforts made to encourage exclusive breastfeeding as the dominant feeding practice. ${ }^{1}$ The total duration of breastfeeding in Brazil is 342 days, considering the exclusive breastfeeding time of 54.1 days, as shown in the 2nd Breastfeeding Prevalence Study in Brazilian capital cities, the Federal District and 239 other municipalities. ${ }^{2}$ Thus, incongruence exists between recognition of the many advantages of breastfeeding for the baby, mother and family, and poor adherence to this practice.

For premature newborns (PNs), the situation is even more paradoxical because the scientific community recognizes and increasingly divulges the benefits of breastfeeding these babies, highlighting, in addition to nutritional benefits, immunological, economic, endocrinological, neurobehavioral and emotional benefits, including pain reduction and greater tolerance to potentially painful procedures. ${ }^{3}$ Breast milk in natura is considered the most suitable food to meet the specific demands of PNs, promoting their proper growth and not producing undesirable metabolic effects. This fact classifies it as the "gold standard" of feeding PN babies, since the balance and healthiness of their respiratory, liver, hemodynamic, nutritional and immunological function depends on good nutrition, and breast milk is the food most likely to offer such advantages. ${ }^{1,3}$

Nevertheless, exclusive breastfeeding rates among premature babies are even more critical than those for full-term babies, as demonstrated in a study in which the mean age for partial weaning was only 1.4 months, and that for total weaning occurred before the third month of life, ${ }^{4}$ a statistic that reveals the enormous challenge of breastfeeding preterm newborn infants, due to the specificities involved in the context of their care. ${ }^{5}$

This paradox may be the result of several challenges experienced by mothers of preterm infants when seeking to breastfeed their babies, such as: the impossibility of early and continuous contact between mother and child; absence of breastfeeding within the first half hour of life, as recommended by the Baby Friendly Hospital Initiative (BFHI); prolonged separation between mother and child due to the baby's stay in the neonatal intensive care unit (NICU) or intermediate nursery care (INC); lack of systematic routines to orient mothers regarding lactation maintenance techniques during the child's hospital stay, in addition to issues related to the specificities of care for PNs and their often critical health condition. ${ }^{4-6}$

In addition, there is low adherence to effective measures for the promotion, protection and support of breastfeeding (i.e., the Kangaroo Method) by healthcare institutions and/or professionals. ${ }^{3}$ The initiation of suckling the mother's breast or oral feeding of a preterm infant varies, taking, on average, 8.4 days for a $\mathrm{PN}$ to completely assume oral feeding, whether by means of exclusive or complemented suckling at the mother's breast, and up to 47 days in the case of extremely premature infants, ${ }^{5}$ which makes the challenge of breastfeeding inversely proportional to the gestational age of the newborn.

Studies on early weaning by mothers of PNs are scarce, and indicate the following reasons: mothers' belief that their milk is "weak;" problems with breasts and insecurity of women on the benefits of their milk for the child. ${ }^{4,7}$ In addition, aspects related to care routines for PNs, such as lack of access by mothers to hospital and specialized outpatient services, long-term hospitalization of PNs, and rigid hospital routines that impede mothers' stay in and/or access to the NICU, which encourage maternal stress. ${ }^{6,8}$

However, it is known that early weaning of a child should not be attributed to isolated and specific aspects, but rather the sum of factors linked to the mother, baby and family, and the context into which they are inserted, including social and economic interference to which they are subject in a given time and space, since, besides being biologically determined, breastfeeding is socially conditioned, and this conditioning tends to overlap with biological determinants of the act of breastfeeding. ${ }^{9}$

Reflecting on the universe of mothers of preterm newborns, it was perceived that prematurity itself imposes a new rhythm and view on the issue of breastfeeding and early weaning, so that the experiences of women in this particular context make their decision to continue breastfeeding or wean early more complex, and require specific actions by the professionals involved in the neonatal care of the PN. Such actions should pervade the support, promotion and protection of breastfeeding, and consider the maternal point of view, seeking to know the reality of weaning based on her own frame of reference, considering that this frame of reference is constructed based on the interactions she establishes with herself, her premature baby, 
the healthcare team and her family. It is essential to reveal how the mother interprets her experiences during this period, and which situations she defines as triggering the process of early weaning of her child.

Therefore, the objective of this article was to reveal maternal experiences with specificities of prematurity that hinder breastfeeding during hospitalization of their babies in the Neonatal Intensive Care Unit.

\section{METHODS}

This was a qualitative study that used Symbolic Interactionism as the theoretical framework, premised on the analysis of the human experience through interaction of the individual with their social reality, which leads to a process of signification for each experience and guides their action. ${ }^{10}$

Interpretive Interactionism was used as the methodological framework, which seeks to obtain dense and detailed descriptions of experiences that trigger signification or reframing, referred to as epiphanies. These change the perception of the subject on a given reality, or trigger processes of signification for hitherto indifferent situations. ${ }^{11}$

The study included 13 women who received care at a follow-up outpatient care clinic linked to the Department of Health of the municipality of Montes Claros, in the southeastern Brazilian state of Minas Gerais, between September 2010 and June 2011. The clinic began operating in August 2007, with the mission to provide care to PNs with less than 34 weeks of gestation weighing less than 2,000g, whose mothers live in Montes Claros. These mothers' PNs were treated in one of the two county public hospitals which are accredited with the title of "Baby-Friendly Hospital". The service has a multidisciplinary team that includes physicians (pediatricians and other specialties such as cardiology and neurology), a physical therapist, a speech therapist and a nurse.

Mothers of PNs whose delivery occurred at less than 34 weeks of gestational age were included in the study, whose infants were hospitalized in an NICU of one of the two hospitals referenced above, and that introduced foods or liquids other than breast milk to their babies before the sixth month of life. Mothers whose children had congenital or acquired defects that could prevent or hinder breastfeeding were excluded. The number of participants was defined by the data saturation criterion. ${ }^{12}$
Data was collected by means of semistructured and audio recorded interviews with the mothers, performed in a private room of the outpatient clinic between the second and the tenth month after hospital discharge of their preterm newborn, in conjunction with their follow-up visits. However, for most study participants, complete weaning of their babies had occurred by the 40th day post-discharge. The interviews were guided by the following questions: How was the process of feeding your child, from birth to discharge? How did you decide to give other milk or foods to your child after leaving the hospital? Other questions were also formulated during the interview in order to deepen understanding of the concepts expressed by the mothers.

After each interview, these were completely transcribed in order to be analyzed concurrently to their collection, following the guidelines proposed by the Interpretive Interactionism: delimitation of the question, "deconstruction" and critical analysis of the priority conceptions of the phenomenon, capture or seizure of the phenomenon, breakdown/reduction of the phenomenon, construction or reconstruction of the phenomenon and contextualization. Hence, after transcribing and reading the interviews, meaning units were identified, which were grouped by similarity, giving rise to the thematic categories that revealed the epiphanies. ${ }^{11}$

Ethical standards for research involving human subjects were adhered to, and all the participants signed a Free and Informed Consent Form, as established by resolution 196/96 of the National Health Council. The follow-up outpatient clinic authorized data collection, and the study was approved by the Research Ethics Committee of the Universidade Federal de São Paulo (UNIFESP), under protocol $n^{\circ}$. 0679/10. In order to maintain anonymity, each mother received the name of a flower.

\section{RESULTS AND DISCUSSION}

Data analysis revealed that, in the perceptions of the mothers, challenges to breastfeeding are related to the specificities of their baby being premature. Thus, the epiphany "Interacting with the specificities of prematurity that hinder breastfeeding", presented in this article, reveals the mishaps and obstacles experienced by the mothers, and the prominent space that these occupy in the women's lives, making breastfeeding a secondary issue, the establishment of which necessarily occurs late. 
In this context, the mother begins to deal daily with the fear of losing her child, anguish from the time of separation from, and clinical instability of, the PN, and the stress involved in order to maintain her lactation.

The difficulties experienced by the mother from the time breastfeeding becomes a reality for her, the PN and the healthcare team, were also revealed. With the introduction of breastfeeding, a new context is unveiled, which is confronted with maternal definitions of breastfeeding existing up to that point. From that moment of closer interaction with the child, the mother discovers that the act of breastfeeding is not as easy as she imagined, since the premature baby presents a differentiated suction pattern, and the act of suckling the breast may represent to the mother a threat to the child's weight gain, as shown in the thematic categories that integrate this epiphany.

These are described below, illustrated with quotes extracted from the mothers' statements, and discussed in light of the literature.

\section{Experiencing the torment of hospitalization and fear of death of the premature baby}

The experience of hospitalization of their premature child is so hard for the mothers that they define it as a torment, a moment of stress and apprehension and something to be forgotten. The impact of this experience is so great that it may even end up impacting the mothers' physical and mental health, which can determine early weaning.

I believe that my milk dried up more. It was this torment, there in the hospital, where I was for those two months [...]. The period he was hospitalized was very difficult [...]. Every day we went there, and every day he'd had a relapse, you know? He had gotten worse. So, it was so hard! (Dahlia).

I believe that the weaning was due to several factors [...]. The psychology that I spent with the girls in the ICU, and going there every day, the stress that we had on a daily basis from the ICU. So, I think this whole process did not help (Hibiscus).

I think it affects us emotionally [...]. And they asked us to calm down, because the more nervous I got, the more my milk decreased (Gardenia).

The hospitalization of the PN changes the family routine, which comes to be marked by fear of what could happen to the child, perceived especially in its fragility. This perception is in congruence with some authors who claim that the birth of a PN newborn represents a limited period of family imbalance, during which parents can be shaken to the point that they have difficulty understanding the directions of the healthcare team.,13

The experience of hospitalization of the child in the NICU is marked in the family's life because, in the collective imagination, the NICU environment is associated with the idea of finitude and imminent possibility of death, and therefore demands strategies for social, emotional and psychological reorganization of the mother and family, and this reorganization is crucial in the process of bonding and establishment of breastfeeding. ${ }^{14}$

In this study, the anguish and family stress generated by the insecurity as regards the wellbeing of the premature infant were defined as hindrances to the establishment of breastfeeding, perceived as part of the context that surrounds the premature arrival of the child. This perception is reinforced in the face of situations of clinical instability of the baby, when parents begin to consider their loss in a more real perspective, and may be related to the maternal attempt to postpone bonding with the child, in an attempt at self-preservation and to prevent suffering, given the risks associated with prematurity. ${ }^{14}$

Maternal fears generated by the unstable clinical situation of the baby require the mother to live with the possibility of loss of her child in a more tangible manner. In this scenario of uncertainties, the survival of the baby assumes all of her attention, while other issues become secondary, including breastfeeding. This finding can be perceived in the lines below.

One day you get there [to the NICU], and they are great, and you leave overjoyed, and then the next some little problem happened, and you leave devastated! (Hibiscus).

I think the worry was too much when he was hospitalized in there! He was there alone! Sometimes I would arrive and they would say: 'Acacia, don't go in there now because the doctor wants to talk to you!' From the time I left home it was already a worry! He was on my mind the entire time! I wanted to fight for him to survive! (Acacia).

During the hospitalization, as the preterm newborn becomes clinically stable, and the mother can participate more directly in the routine care such as helping with bathing, her self-confidence begins to recover. ${ }^{15}$ Once they start to interact with the child, the mother/family begin to perceive it as more than its fragility. ${ }^{13}$ 
In this context, nursing can be a differentiating factor in facilitating the process of adaptation by the family, including the parents in early care of the baby, and seeking relevant and effective communication which considers the individuality and uniqueness of every family and newborn, respecting cultural aspects and considering the social network of support available in each case. ${ }^{15}$ Thus, nursing contributes to reduce anxiety and fear, ${ }^{16}$ and generates support so that the mother can return more quickly to breastfeeding.

The authors of this paper support the early entry of parents into the NICU and their encouragement to participate in the care of the baby, as recommended by the Ministry of Health. According to the ministry, the mother can only interact with the child in a more concrete manner in the most advanced stage of her psychological and affective organization, in which a reorganization of her identity occurs, leaving the role of daughter to assume that of a mother, from wife to progenitor, from worker to mother of family. ${ }^{1}$ At this point, the mother feels safer interacting with the child through physical contact. However, the evolution of stages of psychological organization of the woman and family depends on how the parents are welcomed into the NICU service and the frequency and precocity of these contacts. ${ }^{1}$ Strategies to this end are showing to be effective in reducing anxiety and facilitating the family bond.

It is worth noting that the healthcare services included in this study comply with the recommendations of law no. 11,108 from 2005, which ensures the presence of a partner chosen by the woman during labor, childbirth and the immediate puerperium. ${ }^{1}$ The hospitals in this study allow early and continued contact between PNs and parents, however, such measures need to be encouraged more systematically and comprehensively.

The initiation of breastfeeding and maternal interpretations, based on the mothers' interactions with this process, are described in the following category.

\section{Late initiation of breastfeeding}

Sometimes, the experience of breastfeeding is postponed until the infant is discharged from the NICU, when the mother and the baby are already in the infirmary for medically stable PNs. In this study, breastfeeding usually occurred after discharge of the babies from the NICU environment. In some cases, until the time comes to place the child on her breast to suckle, the mother breastfeeds indirectly by pumping her milk. However, she does not recognize this as a form of breastfeeding, even though she is offering her pumped milk to her child.

When he went to the infirmary, he breastfed for the first time [...]. I took the milk every half hour because I was very nervous with him there, and went to walk and see if it improved a little bit, because I was really nervous! (Jasmine).

As soon as he was born, I was having a lot of milk. I pumped at the hospital and at home (Dahlia).

I pumped for 23 days, every day, at home and in the milk bank, every three hours. There were days when I pumped three glasses of milk! (Violet).

I pumped milk in the milk bank, they pasteurized it and gave it to him. But he only received it via probe, just $2 \mathrm{ml}$ (Gardenia).

For the mothers, breastfeeding is conditioned to the act of the baby suckling directly from the breast, while babies who receive pumped milk by means of a probe or glass are considered to be "suckling". ${ }^{3}$ The mothers also believe that the fact that they cannot place the child to suckle directly on their breasts from the beginning leads them to a certain disinterest in the breastfeeding process, as can be observed in the following statements.

And, also, from the period that I did not breastfeed [...]. Maybe if I had breastfed from day one, from the day he was born, I would have had enough milk for him, but since I went more than two months without breastfeeding [...] (Amaryllis).

I believe that when a child is born and immediately latches on to the breast, he has a much greater bond with breastfeeding than when he, as in my case, goes to the NICU. Only after I went there to encourage him to take it, but he no longer had that need, that angst that you see babies having with the breast, that thing about breastfeeding! I noticed that (Bromeliad).

The study revealed that during the stay in the NICU, some mothers who managed to perform breast milk pumping did so in an unsystematic manner for a short period of time. This is another negative aspect in the lactation process, the success of which depends on early contact between mother and baby, and frequent and continued milking initiated in the early hours of the puerperium. ${ }^{1,3}$

It is important that the mother be monitored and encouraged by the healthcare team in her attempts to pump milk, which can be done in the NICU, ensure that adequate care is taken to preserve the microbiological safety of the milk, and that consumption is immediate. Therefore, the 
early entry of parents into the NICU, encouragement that they participate in the care of their baby and support for milking should be regarded as effective strategies in reducing anxiety, facilitating family ties and promoting breastfeeding. ${ }^{1}$

It is noteworthy that, among the prerogatives of the BFHI, of which the services involved in this study are signatories, the fifth states that the health team should show mothers how to breastfeed and how to maintain lactation, even if they are separated from their babies. ${ }^{3}$ Another aspect that must be observed by the team regards pumping, which must be carried out a minimum of eight times in 24 hours for 15 to 20 minutes, regardless of milk production, until the baby is able to suckle the breast. ${ }^{1}$ For this purpose, the health team must ensure, in addition to information, necessary inputs such as sterile vials, caps and masks, and a suitable environment for pumping during the period in which the mother is in the institution, and support her to pump at home.

Other issues perceived by mothers, such as unfavorable aspects of breastfeeding, are revealed in the category presented below.

\section{Seeing suckling as something difficult and a threat to the child's weight gain}

When the mothers try to place their premature infant to suckle their breast, they realize that the act of breastfeeding is not as simple as they had expected, and is often loaded with restrictions, requiring help from other professionals. The mothers of this study reported that the difficulty of PNs to effectively suckle and empty the breast also constituted a barrier to breastfeeding. These women identified the need for training and encouragement so that their babies could effectively suckle, and the reality of difficulty confronted their preconceptions about suckling, understood until then as a reflective behavior. The following statements elucidate this fact.

At first, it was very difficult! Help from the speech therapist was necessary to encourage him to learn to suck. At first, he did not immediately pick it up; it was very difficult! So, it was very complicated! (Bromeliad).

At the hospital, the nurse said: Whether you have milk in the breast or not, put your child to suckle! I put him [on my breast], but he couldn't suckle (Poppy).

Then, after Mwent to the room and the time came when she could suckle, we put $M$ on the breast and used a probe on the breast for her to suckle (Hibiscus).
This new experience led to the mothers' reframing of the phenomenon of breastfeeding as something more complex, which requires training, vigilance, knowledge and professional skills of speech therapists and nurses, in addition to mother and child, countering the socially constructed image of breastfeeding.

The rhythm and suckling pattern of PNs are differentiated, and suckling can be slow and deep, followed by swallowing and a pause, or frequent and disorganized, without a pause to swallow, which justifies the need for oral training in order to coordinate suckling, swallowing and breathing, especially in newborn infants younger than 34 weeks of gestational age. ${ }^{3-4}$ Exercises to stimulate sucking facilitate the transition from enteral diet to breastfeeding, reducing the total hospitalization time. ${ }^{5,7}$ However, it is important to instruct mothers that the situation is temporary.

In addition to recognizing the different suckling pattern, the mother perceives the act of suckling as a threat to the child's weight gain. In this study, this perception was reinforced from the maternal experiences in the hospital, where the baby's weight gain is important and one of the main aspects evaluated by the healthcare team in making the decision to discharge the baby. Thus, the mother interprets the movement and guidance of the healthcare professionals on this topic, and deduces that the best form of feeding is that which contributes to attaining this objective in the shortest period of time.

When listening to guidance from the healthcare team that her child must suckle for a controlled time, the mother deduces that the baby suckling on the breast may pose a threat to its weight gain, even though the team talks about the importance of breastfeeding and she expresses the desire to maintain or restart it, as shown in the following statements.

At first, they were in the ICU, and I could not breastfeed them, because their weight was very low [...]. They couldn't suckle because of their low weight (Hibiscus).

In the infirmary, they put them [on the breast to suckle], but they said she could not suckle a lot, in order not to lose weight [...]. They said: 'Place her on your breast for a little while'. Then she had to suckle a little while; if she suckled a lot, she would lose weight (Rosa).

On the first day, they asked for milk to put in the probe. I had the desire to breastfeed and asked if I could put him on my breast [...] The nurse helped me 
to give milk in the cup so that he would not exert so much energy and we could leave sooner (Bromeliad).

In this study, as illustrated in the participants' statements, the perception of the PN suckling the breast as a risk to their proper weight gain was shared by members of the healthcare team, even though the literature recommends that oral feeding of preterm infants is started early, whenever possible, and preferably by suckling at the breast. . $^{2-3,17}$

In addition, the WHO recommends that the infant's contact with the mother's breast is done as early as possible, even if, at first, just to "lick it." ${ }^{3}$ In one study evaluating the benefits of stimulating suckling by means of the "empty breast" technique, a reduction in hospitalization time of preterm infants was observed, ${ }^{18}$ which reinforces the absence of a causal link between suckling and weight loss of the premature newborn. Other advantages attributed to the "empty breast" technique include the fact that it is more physiological, enhancing the development of the oral sensorimotor system, and promoting tactile and gustatory stimulation. It also promotes the emotional bond between mother and child, maternal inclusion in neonatal care, and facilitates maintenance of lactation, since the mother should pump milk from the breast before offering the breast to the child. ${ }^{18}$

In addition, weight and gestational age, criteria generally used in NICU services to allow PNs to breastfeed, should not be taken as the only parameters, since suckling is a complex function that requires the PN to have oral motor skills, physiological control, coordination of suckling, swallowing and breathing, and tactile responses to stimuli. Studies show that the sooner suckling is stimulated, the sooner it will be developed, so that as soon as the PN reaches a full diet by means of gastric tube, they should be evaluated for the possibility of transition directly to the mother's breast.,17 However, the dietary transition occurs in different ways in NICU services, and is one reason for discussions and disagreements among the healthcare team. In addition, there is no consensus on the best techniques and food supplement administration routes in order to maintain breastfeeding, ${ }^{5}$ which contributes to different professional positions and hospital routines on the issues.

Thus, it is the healthcare team's responsibility to seek strategies that encourage breastfeeding, such as help handling and correct positioning; pumping the previous, low-calorie milk to be offered, if necessary, after breastfeeding; adopting different positions such as reverse feeding and the horse riding position; and orientation and exercises, coordinated by a trained professional, for effective suckling by preterm infants with less than 34 weeks corrected gestational age. ${ }^{3}$

Specifically for PNs, the ten steps to successful breastfeeding in the NICU should be expanded to adopt three more: 1) team focus on the mother and her situation; 2) provision of care centered on the family; and 3) continuity of pre, peri and postpartum care after discharge..$^{19} \mathrm{With}$ regard to home care, some authors ${ }^{20}$ highlight the importance of strengthening the link between the primary healthcare unit and the families of PNs in order to ensure continuity of effective and differentiated care for these babies. The itinerary of families of PNs is also marked by fragile links with primary care services and barriers to access such services, which creates uncertainty and dissatisfaction on the part of the family, and contributes to ineffectiveness of follow-up care for the premature infant. ${ }^{20}$ Thus, lack of continued support for the family of PNs also interferes with the maintenance/resumption of breastfeeding as the dominant food practice.

In addition, the adoption of evidence-based measures should be implemented by healthcare services, such as the kangaroo care, hospital accommodation or transportation support for mothers to the milk bank, adoption of trophic feeding in the NICU, and training of the team involved in the care for families of preterm infants in the different levels of care, in the course of breastfeeding counseling. ${ }^{3}$

\section{FINAL CONSIDERATIONS}

Breastfeeding of PNs is a challenge to those involved in the process, a result of the specificities related to prematurity. Yet professional conduct and hospital protocols can facilitate this practice, if effective measures are adopted for continued support to the mother and family, and the promotion, protection and support of breastfeeding is sought, taking into account its singularities.

The results of this study indicate issues that must be reflected by the professionals involved in neonatal care, including the importance of systematized family support during the period of hospitalization of the baby, facilitating the motherchild-family bond, and updating routines related to infant nutrition and the development of PNs based on scientific evidence. It is essential that the healthcare team provides the human, logistical and 
technical support necessary for the performance of breastfeeding preterm newborns, and adopt a more favorable attitude to this practice, considering the importance of this in the process of maternal significance of breastfeeding and weaning.

Furthermore, it is important to seek the incorporation of the BFHI recommendations, for although considered an effective strategy to promote breastfeeding, in the reality of Brazil, they are not enough to improve professional attitudes and hospital routines favorable to maintaining breastfeeding among mothers of PNs, especially in the NICU environment. In fact, most situations recognized by the mothers as hindering breastfeeding occurred due to a professional approach unfavorable or insufficient to generate the necessary support for this practice.

The fact that the study was carried out only with a population cared for in hospitals that hold the title of BFHI, and accompanied in follow-up outpatient care of the PN, constituted a limitation of this study, since populations exposed to other types of care could reveal other experiences, expanding understanding of the phenomenon studied.

Furthermore, we believe that intervention studies on other possible approaches to the management of breastfeeding among this population should be performed, considering the specificities involving neonatal care and the importance of breastfeeding for the health of preterm newborns.

\section{REFERENCES}

1. Ministério da Saúde (BR), Secretaria de Atenção a Saúde, Departamento de Ações Programáticas Estratégicas. Atenção Humanizada ao RecémNascido de Baixo Peso: Método Mãe Canguru. $2^{\circ}$ ed. Brasilia (DF): MS; 2011.

2. Ministério da Saúde (BR). II Pesquisa de Prevalência nas Capitais brasileiras e Distrito Federal: aleitamento materno. Projetos, Programas e Relatórios. Brasília (DF): MS, 2009.

3. Organização Mundial da Saúde. La alimentación del lactante y del niño pequeño: capítulo modelo para libros de texto dirigidos a estudiantes de Medicina y otras ciencias de la salud, Washington (US): OPS; 2010.

4. Silva SMS, Segre CAM. Fatores que influenciam o desmame no recém-nascido prematuro. Rev Bras Crescimento Desenvolv Hum [online]. 2010 [acesso 2012 Dez 10]; 20(2). Disponível em: http:/ / pepsic.bvsalud.org/scielo.php?script=sci_ arttext\&pid=S0104-12822010000200012\&lng=pt\& nrm=iso
5. Scochi CGS, Gauy JS, Fujinaga CI, Fonseca L MM, Zamberlan NE. Transição alimentar por via oral em prematuros de um hospital amigo da Criança. Acta Paul Enferm [online]. 2010 [acesso 2013 Jan 23]; 23(4). Disponível em: http://www.scielo.br/pdf/ ape/v23n4/15.pdf

6. Scochi CGS, Ferreira FY, Góes FSN, Fujinaga CI, Ferecini, GM, Leite AM. Alimentação láctea e prevalência do aleitamento materno em prematuros durante internação em um hospital amigo da Criança de Ribeirão Preto-SP, Brasil. Cien Cuid Saude [online]. 2008 [acesso $2012 \mathrm{Dez} 15]$; 7(2).Disponível em: http:/ / www.scielo.br/scielo.php?script=sci_ arttext\&pid=S0103-21002010000400015

7. Alves AML, Silva EHAA, Oliveira AC. Desmame precoce em prematuros participantes do Método Mãe Canguru. Rev Soc Bras Fonoaudiol [online]. 2007[acesso2012 Nov 12]; 12(1). Disponível em: http:/ / www.scielo.br/scielo.php?script=sci arttext\&pid=S0103-21002010000400015

8. Machado MMT, Bosi MLM, Braga DF. Amamentação exclusiva de recém-nascidos prematuros: percepções e experiências de lactantes usuárias de um serviço público especializado. Rev Nutr Campinas [online]. 2008 [acesso 2012 Nov 12]; 21(3). Disponível em: http://bases.bireme.br/cgibin/wxislind.exe/iah/online/?IsisScript=iah/iah. xis\&nextAction $=1 n k \& b a s e=$ LILACS\&exprSearch $=$ 487550\&indexSearch $=$ ID\&lang $=p$

9. Pereira LB. Ressignificando o aleitamento materno - do ideal ao impossível: o caminhar da mãe do bebê prematuro rumo ao desmame precoce [tese]. São Paulo (SP): Universidade Federal de São Paulo, Programa de Pós-Graduação em Enfermagem; 2013.

10. Charon JM.Symbolic Interactionism: an introduction, an interpretation, and an integration. $10^{\mathrm{a}} \mathrm{Ed}$. New Jersey: Prentice-Hall; 2010

11. Denzin NK. Interpretive interacionism. Newborury Park: SAGE Publicatino; 1989.

12. Fontanella BJB, Luchesi BM, Saidel MGB, Ricas J, Turato ER, Melo DG. Amostragem em pesquisas qualitativas: proposta de procedimentos para constatar saturação teórica. Cad Saude Publica [online]. 2011 [acesso 2012 Fev 8]; 27(2). Disponível em: http:/ / www.scielo.br/pdf/csp/v27n2/20.pdf

13. Iungano EM. A relação entre a mãe e o bebê prematuro internado em UTI neonatal. Psciol Pediatr [online]. 2009 [acesso 2012 Mai 8]. Disponível em: http://www.moreirajr.com.br/revistas. asp?fase=r003\&id_materia $=3974$

14. Schmidt KT, Sassá AH, Veronez M, Higarashi IH; Marcon SS. A primeira visita ao filho internado na unidade de terapia Intensiva neonatal: percepção dos pais. Esc Anna Nery [online]. 2012 [acesso 2013 Jan 20]; 16(1). Disponível em: http:/ / www.scielo.br/scielo.php?script=sci arttext\&pid=S1414-81452012000100010. 
15. Souza N, Pinheiro-Fernandes AC, Cruz-Costa ICC, Enders B, CarvalhoJBL, Silva MLC. Domestic maternal experience with preterm newborn children. RevSalud Publica. [online]. 2010 [acesso 2012 Nov 15]; 12(3). Disponível em: http://www.scielo.org.co/scielo. php?script=sci_arttext\&nrm=iso\&lng=pt\&tlng $=$ pt\&pid=S0124-00642010000300002

16. Conz CA, Merighi MAB, Jesus MCP. Promoção do vínculo afetivo na Unidade de Terapia Intensiva Neonatal: um desafio para as enfermeiras. Rev Esc Enferm USP [online]. 2009 [acesso 2012 Jan 10]; 43(4). Disponível em: http:/ / www.scielo.br/pdf/reeusp/ v43n4/a16v43n4.pdf

17. Ben XM. Nutritional management of newborn infants: practical guidelines. World J Gastroenterol. 2008 Oct 28;14(40):6133-9.
18. Venson C, Fujinaga CI, Czluniak GR. Estimulação da suç̧ão não nutritiva na "mama vazia" em bebês prematuros: relato de casos. Rev Soc Bras Fonoaudiol [online]. 2010 [acesso 2012 Nov 10]; 15(3):452-7. Disponível em: http://www.scielo.br/pdf/rsbf/v15n3/22.pdf

19. Nykvist KH, Häggkvist AP, Hansen MN, Kilberg E, Frandsen AL, Maastrup R, et al. Expansion of the ten steps to successful breastfeeding into neonatal intensive care: expert group recommendations for three guiding principles. J Hum Lact [online]. 2012 [acesso $2013 \mathrm{Fev} 20]$ ] 28(3):289. Disponível em: http://jhl.sagepub.com./content/28/3/289

20. Viera CS, Mello DF. O seguimento da saúde da criança pré-termo e de baixo peso egressa da terapia intensiva neonatal. Texto Contexto Enferm [online]. 2009 [acesso 2013 Fev 19]; 18(1). Disponível em http://www.scielo.br/pdf/tce/v18n1/v18n1a09 